\title{
EMBROIDERIES AND THEIR TRENDS IN MODERN FASHION A FUSION
}

\author{
Shaik rafia sulthana ${ }^{1}$ \\ ${ }^{1}$ Academic consultant, B.Voc fashion technology and apparel design, \\ sri padmavathi mahila visvavidyalayam university, Tirupathi, Andhra Pradesh
}

\begin{abstract}
An embroidery is an ancient form of needle work that has been used worldwide to embellish textiles for decorative and communicative purpose. An elegant and traditional embroidery have so many techniques and procedures in it. Industrial revolution in embroideries formed a new dimension. Embroideries are being used indifferent ways and on variety of fabrics. Famous fashion designers implement embroideries in their attires. When utilized appropriately, these embroideries with the right mix of floral emblems, designs and abstract patterns, serve as catalyst of a new fashion statement. Embroideries are the pride of the nation and source of the national economy and employment. In this paper, an analysis and preferences of embroideries and the importance given to them by professionals in their robes and suggestions and framework for fusion embroidery into present fashion have been explained
\end{abstract}

Keywords: embroidery, modern fashion, fusion

\section{INTRODUCTION :-}

Even since the early days of fabric, embroidery has played an integral part in human life . From man's basic need for shelter, clothing, storage and transportation, food, started the craft of intertwining, weaving fibers and grasses into stuff dwellings, coarse fabric baskets and containers. This necessity of joining pieces of fabric led to the evolution of a coarse method of stitching which in time became the decorative medium which we know as embroidery.Embroidery is the art of work, comprising ornamental designs on cloth, leather etc, with decorative stitches ${ }^{1}$. There are different kinds of embroidery which are known by special names such as cutwork, drawn thread work, applique, smocking etc. For successful embroidery work, it is essential that we learn to work the basic stitches in addition we should acquire the ability to choose the right kind of stitches designs and colour combinations that suit to the type of fabric and the purpose and the use of the garment (or) article on which the embroidery is to be worked upon. Embroidery is the craft that decorates fabric or other materials using a needle to apply thread or yarn. Embroidery also incorporates other materials such as pearls, beads, quills and sequins. In modern days, embroidery is usually seen on caps, hats, coats, blankets, shirts, denim dresses, stockings, and golf shirts. Embroidery is available with a wide varieties of threads or yarn colour. Some of the basic techniques or stitches of the earliest embroidery are chain stitch, button hole or blanket stitch, running stitch, satin stitch, cross stitch. These stitches remain the fundamental techniques of hand embroidery even today .

\section{DISCUSSION:-}

In terms of form and aesthetics, embroidery patterns as colour, texture, richness used on clothing, foot wear, bags, home furnishings and accessories, it may reveal the warer's wealth, social status, ethnic identity.In Traditional systems of belief or historical importance, embroidery is executed in threads of cotton, wool, silk or zari threads and may also incorporate other decorative materials such as beads, stones ,metal like gold, silver, shells, feathers, motives and other materials. some materials, techniques and stitches are found across many cultures, while others are specific to region.

\subsection{HISTORY OF AN EMBROIDERY:-}

One of the distinctive aspects of indigenous handcrafted textiles is the use of embroidery. Indigenous motifs found on garments range from geometric patterns, zig-zag, spirals, moons, crosses and stepped frets. Thin cloth belts that wrap around the waist called as fajillas are common in a number of indigenous groups and are richly embroidered. The borders are often adorned with zig-zag edging like those of Huichols ${ }^{5}$. Flower designs are popular for embroidering women's clothing among the otomis ,nahuas, huastecs ,huichols and others. Spirals and curved designs appear frequently, especially in the center and south of the country. in addition to flowers,other themes from nature in woven and embroidered designs include plants ,animals such a squirrels, rabbits, deer, armadillos, doves, humming birds, pelicans, seagulls and fish. The cloth napkins of san manteo del mar have images of aquatic birds such 


\section{International Advanced Research Journal in Science, Engineering and Technology}

Vol. 8, Issue 6, June 2021

\section{DOI: $10.17148 /$ IARJSET.2021.86103}

as pelicans and seagulls, with those of tacuate of Santiago zacatepac have borders with many diminutive animals like centipedes, scorpions ,birds, iguanas cats, foxes and more. Human figures appear with relative frequency as well.

The textile tradition of india was influenced by cotton. the textile craftmen found their richest expression in growing, spinning, weaving, dyeing, printing and embroiderering of the cotton. over two thousand years ago the artha shastra refers to textiles design workshops being established under the patronage of maurya kings. these workshops employed proficient spinners, weavers and embroiders. royal karkhanas or workshops flourished under the patronage of the mogul emperors. textiles of rare elegance and sophistication were woven, painted and embroidered in the these workshops by the finest craftsmen in the country. In vedic age Indian women wore the gorgeous ornamental tested borders in their long piece of prototype saree.

\subsection{DEVELOPMENT OF THE MODERN EMBROIDERY TRENDS :-}

The word embroidery is derived from the French word broderie ,meaning embellishment. Embroidery is practiced across the world. it's origin is found from china and the near east. Early embroidery can actually be traced back to 30,000 B.C . Archeological finds found from this time period reveals fossilized remains of heavily hand stitched and decorated clothing. Embroidery was important in the medieval Islamic world because it was a sign of high social status in muslim societies. Embroideries could be found on items such as handkerchiefs ,flags, uniforms , robes, horse trappings, pouches and covers. In $18^{\text {th }}$ century England and it's colonies, embroidery was a skill marking a girl's passage into womanhood as well as conveying rank and social standing. Soon after however, the development of the embroidery machine and mass production came into existence about in stages during the industrial revolution. The earliest machine embroidery, found in France in the mid-1800s, utilized a combination of machine looms and hand embroidery, And around the year 1900, mail order catalogs and pattern papers helped embroidery become more widespread.

Embroidery was no longer just the part of the upper class. As it can now be done on cheaper materials. Further more, while embroidery was historically performed primarily by women, the art of embroidery is now being enjoyed by men. During an interview, famous actor Henry Fonda revealed that embroidering was his favorite hobby. Another famous male embroiderer was Gustaf v, king of Sweden during period between 1907 and 1950. Most famous Indian fashion designer's play an important role in an embroideries and also in economy of the country. They are designing most gorgeous bridal outfits to the brides. Every Indian bride's beautiful dream is to wear the most famous designer's outfits . indian Designers are using different fabrics colours and embroideries have influenced the Indian fashion scene and are bringing Indian handicrafts and fabrics to the international level. Sabyasachi mukherjee, manish malhotra ,tarun tahiliani , anju modi , anamika khanna, ritu kumar, neeta lulla their designer out fits are famous because of the stunning unique embroidery and best quality of material, fabrics and colours along with extra ordinary designs Each beautiful embroidery outfit takes atleast 6 months to 1 year to transform into an elegance. this is the speciality of an embroidery .

Today's embroidery model looks a lot different from the embroidery of the past. Most contemporary embroidery is stitched with a computerized embroidery machine using patterns that are "digitized"on a computer software. while the style and technique of modern embroidery remains the same. Embroidery has and always will be a popular way for people to decorate their homes and themselves with personalized brands and $\log o{ }^{9}$. Blessed with a myriad of cultures, customs and religions, india is truly a land of wonders. one of the greatest treasures of the country is it's art and craft. Be it dance, music or paintings, this melting pot of cultures has given us some of the best art and craft forms that are envied all over the world ${ }^{8}$.one such craft is the Indian embroidery that is adverse yet distinct with testimony of rich culture and heritage .Embroidery in india has come a long way, as fashion trends changed with time, Indian embroidery adopted to the new climate and managed to remain elegant and sophisticated. while each embroidery technique possesses it's own speciality, it is for certain that each one of them makes a serious style statement.

\subsection{TYPES OF EMBROIDERIES:-}

There are two types of embroideries. 1. basic embroidery 2. Traditional embroidery. ( fig - 1 ) Basic embroidery stitches are stem, chain, satin, long and short, flat ,fishbone, herringbone, feather, french knot, lazy daisy. traditional embroidery stitches are phulkari of Punjab, kantha of Bengal , kasuti embroidery of Karnataka, kashida of Kashmir, chikankari of lucknow uttar Pradesh , chamba rumals, sindhi embroidery ${ }^{6}$.

\subsection{MATERIALS USED IN EMBROIDERY:-}

fig -2 )

Embroidery frame, embroidery scissors, embroidery threads, needle, needle threader, thimble, stiletto. (

\subsection{Procedure of the embroidery:-}

Any simple plain cloth that is transformed artistically by fancy design comprises embroidery ${ }^{7}$. it is very important to have knowledge of proper mixing of colours to get good embroidery work ${ }^{10}$. Embroidery is created by the decorative relationship between fabric and thread. it is important to acquire a through knowlwdge and understanding of materials and methods and to be able to use them effectively. there are many fabrics are available in the market. We can choose any fabric according of our choice .but linen is perhaps easiest to embroider. Embroidery 


\section{International Advanced Research Journal in Science, Engineering and Technology}

Vol. 8, Issue 6, June 2021

\section{DOI: $10.17148 /$ IARJSET.2021.86103}

frame is recommended to help keep the work flat and even for hand and machine embroidery. scissors is cut for threads. design must be transferred to the fabric. then we can stitch any type of embroidery either by hand,machine through digital and aari work or frame work. Example of the successful embroiders:-

1. Paaro bai native of dandkala village in kolayat of Bikaner district in rajasthan.she is a founding member of ashg and has helped 40 to 50 women of her village to earn income between Rs 3,000 and Rs 5,000 every month. she had trained her daughters, manguri and mathri,who are now married and live in barmer district.they have trained other women of their villagers.women artisan's involvement in kashida work helps them to remain in their villages,rather than migrating to the cities ${ }^{4}$.

2. Born near Rajasthan's Barmer district, 31-year-old handicraft artisan Ruma Devi defied all odds when she created ripples of social change with her simple handmade embroidery - an entrepreneurial movement that has now touched and influenced over 22,000 women at the grass roots and led her to the 'Nari Shakti Puraskar', the highest civilian honour for women in India ${ }^{2}$.

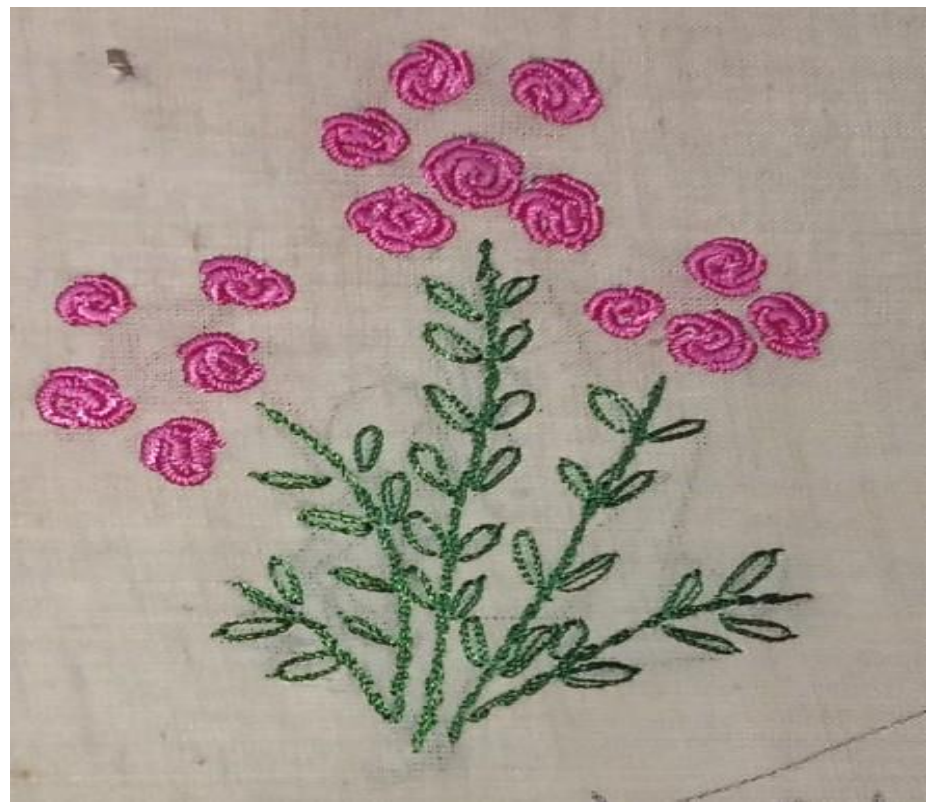

Figure 1 - hand embroidery depicting flower patterns

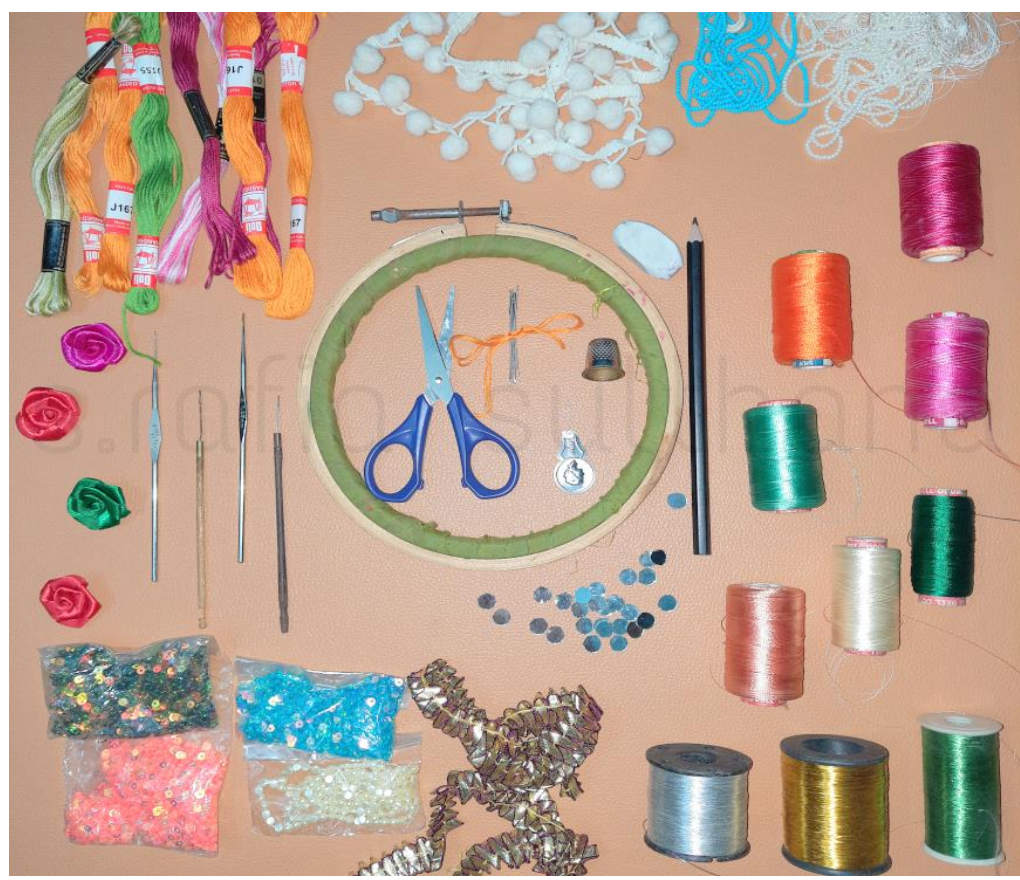

Figure 2 - Picture depicting various materials used for embroidery 


\section{International Advanced Research Journal in Science, Engineering and Technology}

Vol. 8, Issue 6, June 2021

DOI: $10.17148 /$ IARJSET.2021.86103

\section{EMBROIDERIES AND THEIR MODERN PROSPECTS IN FUSION}

A study has been conducted with over 100 participants, comprising professionals involved in textile industry and classified young stream of fashion fusion and the future designers .

3.1 PLACE OF STUDY - Tirupathi, Andhra Pradesh

3.2 CONSENT - obtained from participants who participated in questionnaire .

3.3. MATERIALS AND METHODS - QUESTIONNARE consisting of following questions

1. Which type of method do you prefer in your attire ?

a) Hand embroidery b) aari embroidery c) computerized embroidery d) all of the above

2. Do you want to use the latest patterns of embroideries ?
a) yes
b) no

3. How much percentage of your embroidery you prefer to have older created versions of embroideries ?

$\begin{array}{llll}\text { a) } 25 \% & \text { b ) } 50 \% & \text { c) } 75 \% & \text { d ) } 100 \%\end{array}$

4. which method do you prefer in illustrations ?

a) pen and pencil traditional method b ) machine technique

5. which colors do you prefer in embroidery?

a) primary b) secondary c ) intermediate colours d ) above all

6. which type of fabric you prefer for embroidery work?

a) linen b ) silk c ) crepe d) georgette

7. How much percentage of the garment do you prefer to have traditional hand embroidery ?

a) $25 \%$ b) $50 \%$ c) $75 \%$ d ) $100 \%$

8. Do you think embroidery work is important in your attire ?

a) yes b) no

9. which type of dresses are suitable for embroidery?

a) jeans b ) sarees and ghagra choli c) salwar kameez d ) above all

10. Do you think embroidery enhances the elegance of dress?

a) Yes b) no

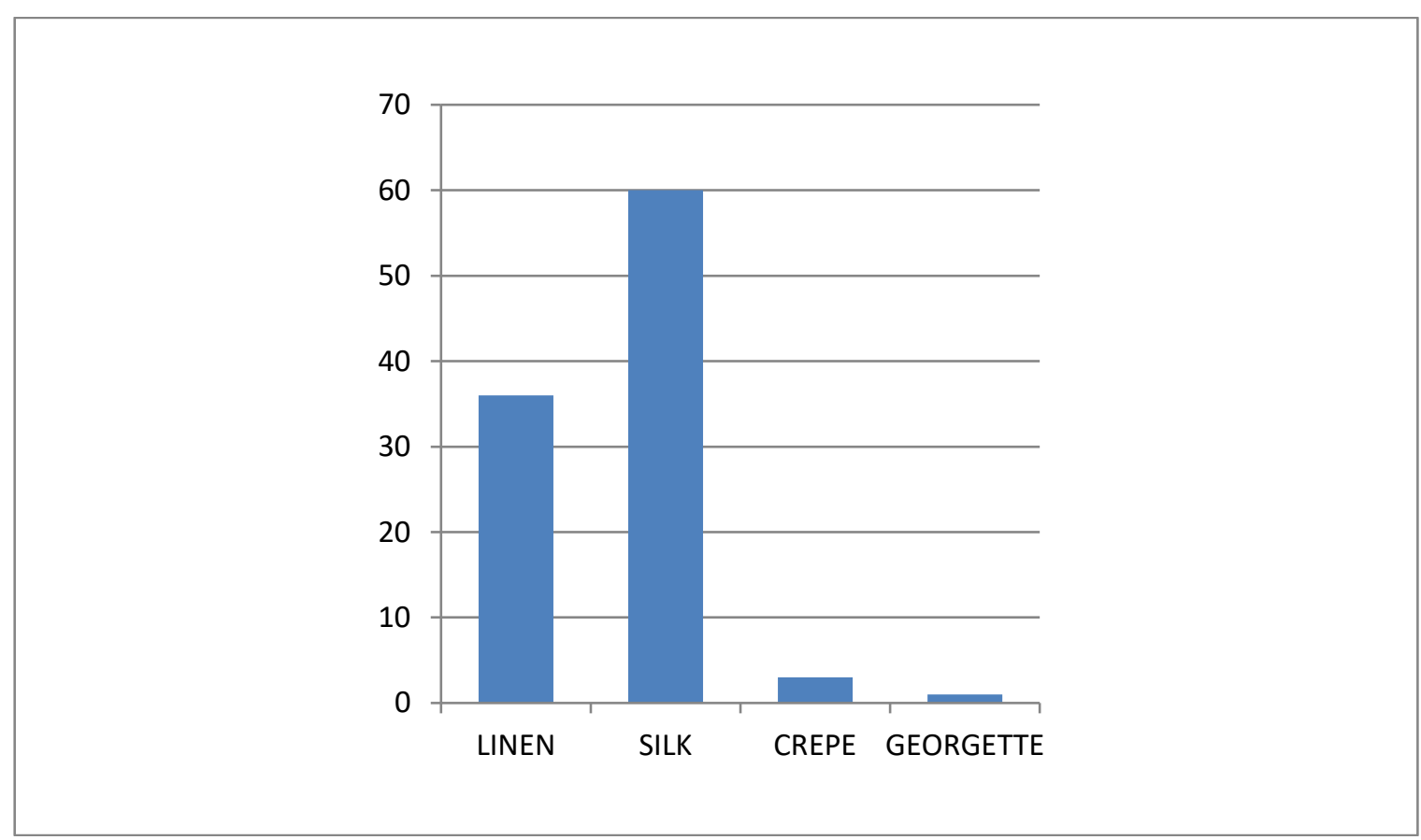

Table 1 - Fabric preference for embroidery 


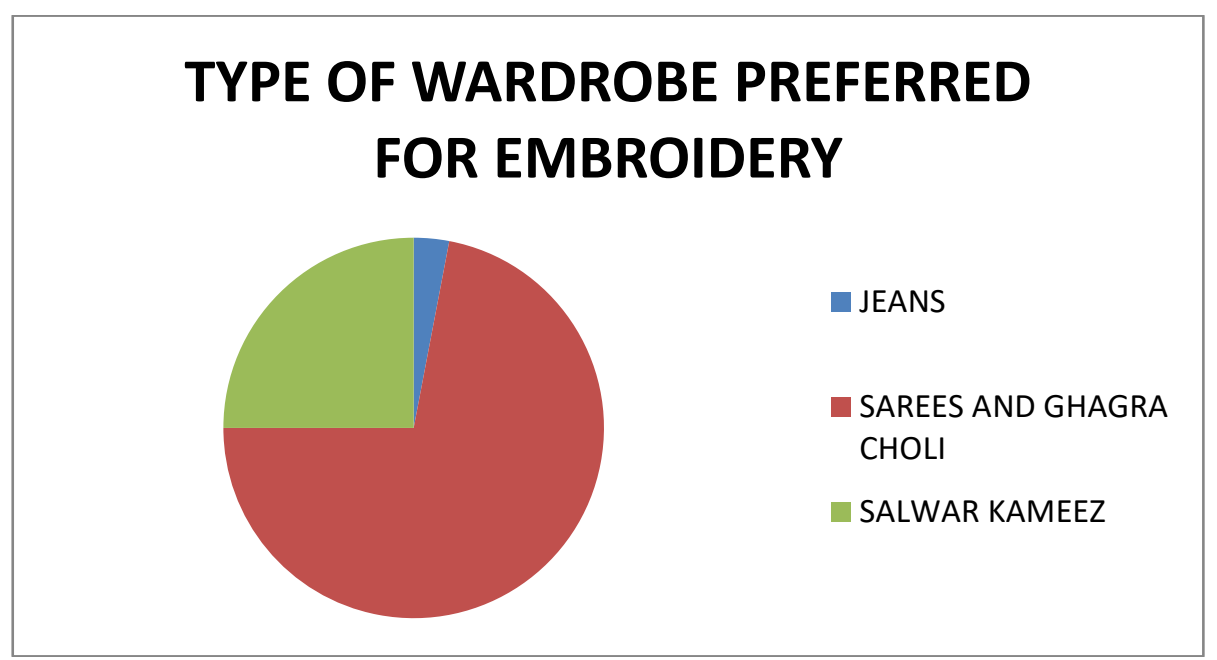

Table 2 - wardrobe preference for embroidery

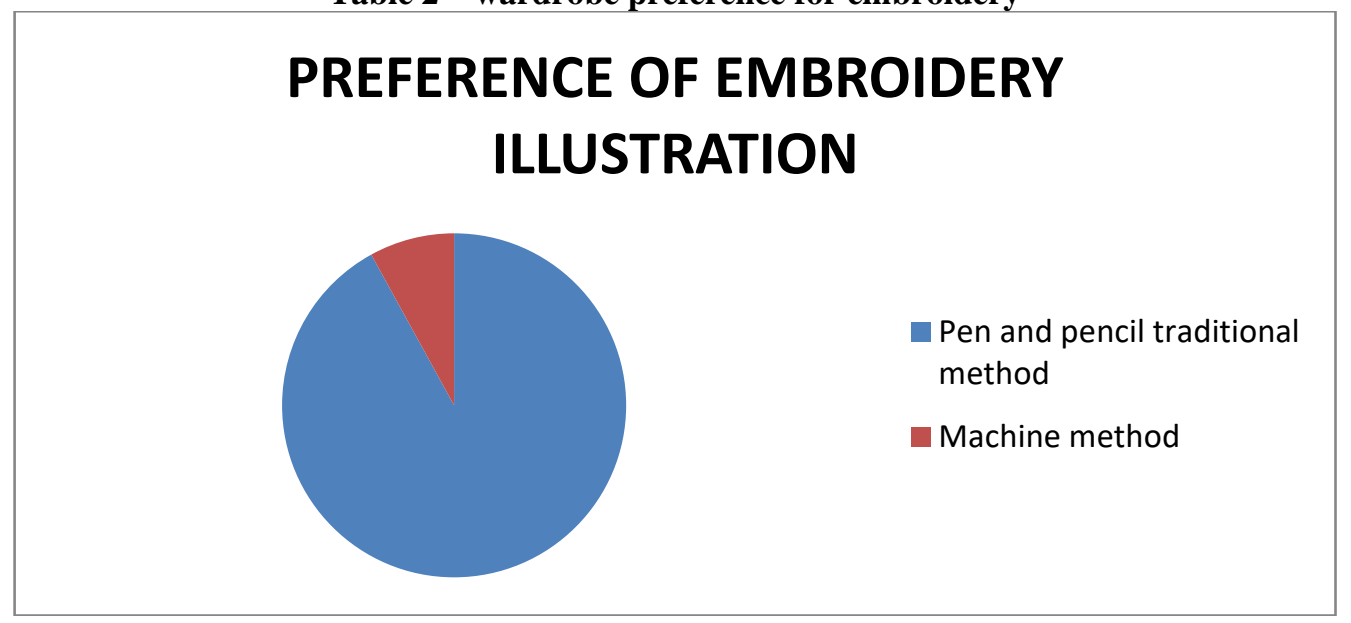

Table 3 - preference of embroidery illustration

\section{SAILENT OBSERVATIONS OF THE STUDY}

1. $70 \%$ Preferred hand, aari and computerized embroidery together.

2. $75 \%$ want to use the latest patterns of embroideries .

3. Very few, around $10 \%$ opted to retain old versions, which shows they need more innovation in designs.

4. $92 \%$ preferred to opt pen and pencil method of illustration over machine technique (table -3 )

5. $82 \%$ preferred to use a fusion of all primary, secondary and intermediate colours in their embroidery patterns

6. $60 \%$ preferred to use silk fabric for embroidery and $36 \%$ opted for linen ( table- 1 )

7. $64 \%$ wanted to use traditional designs in embroideries over modern designs

8. $92 \%$ preferred embroidery work in their designer portfolio and opined it uplifts the elegance of attire

9. $72 \%$ preferred saree and ghagra choli as suitable attire for embroideries, while only $3 \%$ preferred Jeans. (table- 2 )

10. $94 \%$ opined that embroidery should be an essential part of wardrobe and their manufacturing portfolio

\section{ADVANTAGES OF AN EMBROIDERY:-}

1. Embroideries are career opportunities of fashion designers.

2. Embrioderies are the great sources of income.

3. It provides a lot of economical support to the families.

4. It provides an employment opportunity to the common people.

5. Embroideries are beautiful arts and craft of our treasures of the country.

6. Psychologically embroideries give satisfactory outlook to fabric, creating a visual pleasure.

7 . Embroideries enhance the elegance and quality of the attire 


\section{International Advanced Research Journal in Science, Engineering and Technology}

Vol. 8, Issue 6, June 2021

DOI: $10.17148 /$ IARJSET.2021.86103

8. Embroideries potray the rich heritage and culture of the countries and uplifts the importance of the states.

9. This art and craft when taken forward to generations, preserves the heritage of the country

10 . It is an old art and craft of the country.

\section{CONCLUSION}

Embroidery is an art which when blended with colours, patterns and tradition, uplifts and brings elegance and richness to the fabric. With the changing pattern of lifestyles and modernization, it is always essential to keep this unique form of art alive, which can be done with modern fusion and new generation of designers taking forward the legacy with passion and responsibility, while retaining the basic essence of the art. This need and the future trends are clearly evident from the results of this study, thus highlighting the fusion of embroidery in modern fashion.

\section{REFERENCES}

1. Poray D. The Fading Art of Indian Embroidery and Its Impact on Luxury Fashion

2. Onmanorama.com/lifestyle/women/2020/01/14/ruma-devi-rural-women-empowerment.

3. Craik J. The face of fashion: Cultural studies in fashion. Routledge ; 2003 Sep 2.

4. Shazia Begum B A; Punith Cariappa. "Implications of the GST Regime for the Country's Textile Sector". International Research Journal on Advanced Science Hub, 2, Special Issue ICARD, 2020, 281-285. doi: 10.47392/irjash.2020.133

5.H B Siddaraju; Muninarayanappa M. "GST-Triggered Issues That Confront the Country's Textile Sector". International Research Journal on Advanced Science Hub, 2, Special Issue ICARD, 2020, 286-290. doi: 10.47392/irjash.2020.134

6 . Villagesquare.in/2017/05/12/women-artisans-thar-desert-overcome-adversity-embroidery.

7. Embroidery in wikititionary, the free dictionary

8. Textile design- Fiber to fabric : Bernard p corbman, 6thed

9. A text book on Fashion and textile ; s.naik ; 2nded

10. Textile processing printing and dyeing finishing. J I smith ,1st edition

11. sayitwithstitches.net/the-history-of-embroidery, internet

12. Fashion technology, today and tomorrow , nirupama pundir, mittal publication 2008 